Breast cancer incidence rates have increased among women of all races since the early 1980s [710]. The increasing rate involves mainly small and localized stage tumor, although a small increase in regional stage and larger tumor was also observed. The impact of this trend reflects on type of surgery: local biopsies and lumpectomies were operated more than mastectomies and the duration of stay was shorter. However, in this study, the percentage of young patients (age $<40$ ) undergoing lumpectomy or mastectomy is steadily increasing from $3.5 \%$ in 2002 to $6.3 \%$ in 2006 . This trend was also observed in recent epidemiological studies from France and Switzerland $[11,12]$. These studies show that early screening and detection alone can not explain the increase in breast cancer incidence among young patients, because screening and improvement in diagnostic techniques should lead to a shift in stage distribution towards earlier stages, whereas in the populations studied, this did not change significantly.

The introduction of laparoscopic cholecystectomies in the last 20 years was associated with a decrease in the rate of open cholecystectomies and shorter duration rate [13-15]. The same trend was found in this study and the trend has not change during the last 5 years. We observed that patients who underwent open cholecystectomies tended to be older and male, this is consistent with data published by others $[13,14]$.

Most of the unilateral inguinal hernioplasties preformed at our medical center are open whether as most of the bilateral inguinal hernioplasties are preformed laparoscopically. Our data coincides with data shown by McCormack et al., which calculated the cost effectiveness of inguinal hernioplasties, including in-hospital, post-surgical out-of-hospital costs and quality of life assessment [16]. They found that for unilateral inguinal hernias, open hernioplasties is less costly than laparoscopic hernioplasties. For bilateral inguinal hernias, laparoscopic hernioplasties are more cost-effective than open hernioplasties. Our philosophy is to tailor the appropriate kind of surgery for each patient with inguinal hernia. Thus unilateral hernias are performed open and bilateral hernias are performed, if medical condition allows, laparoscopically.

To conclude, in examining the trends of hospital admissions, we mapped the distribution of operative procedures with special attention to urgent operations and to partial resection of large intestines and rectum. We found a decrease in the average hospital stay, and a decrease in mortality without change in the number of admissions or change in procedure volume and distribution. We also found that the hospitalization length of stay and mortality is compatible with previously published data. This information can be extremely helpful in estimating the projected needs for our hospital in the future.

\title{
TENDINȚE PRIVIND INTERNĂRILE PE SECȚIILE DE CHIRURGIE LA UN SPITÁ COMUNITAR DIN ISRAEL
}

\section{Rezumat}

Baze teoretice: Studiile epidemiologice sunt utile atât pentru depistarea posibililor factori etiologici, cât şi pentru determinarea necesarului de servicii şi echipamente sanitare. Într-o încercare de a îmbunătăți calitatea serviciilor, am analizat tendințele privind internările pe secțiile de chirurgie ale Spitalului Hasharon, din Centrul Medical Rabin, Israel.

Metode: Au fost colectate datele tuturor internărilor pe divizia chirurgicală între 2002 şi 2007, incluzând informațiile privind decesele, diagnosticele la externare, durata de internare şi mortalitatea. Sursa datelor a constituit-o baza de date „Bina” a Serviciilor de Sănătate Clalit.

Rezultate: Au fost în medie $4.385 \pm 130$ internări anuale pe secțiile de chirurgie generală, cu o

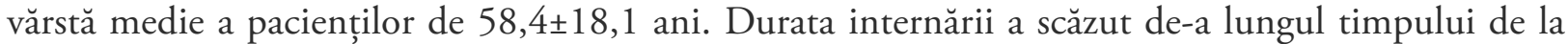


$3,28 \pm 0,25$ zile, la $3,07 \pm 0,17$ zile $(\mathrm{p}=0.006)$. Peste $70 \%$ din internări au fost pentru intervenții în afara urgenței (opționale). Distribuția operațiilor opționale efectuate a fost: 24\% hernioplastii, 13\% operații la nivelul anusului şi 9\% operații pe intestinal gros. Operațiile la nivelul pielii, sânului, veziculei biliare şi vaselor sangvine au avut o proporție asemănătoare ( $9 \%-10 \%)$. Operațiile de urgență au fost în principal pentru fistule sau abcese anale şi apendicectomii. În perioada studiată a avut loc o creştere constantă a procentului de rezecții colice laparoscopice (hemicolectomii drepte şi stângi şi sigmoidectomii), de la 16\% la 37\%. Procentul pacienelor tinere (sub 40 de ani) supuse tratamentului chirurgical pentru cancer mamar a crecut de la 3,83\% la 5,38\% $\left(\mathrm{r}^{2}=0,5\right.$ pentru tendință). Totodată a fost observată o scădere semnificativă a mortalității de la $0,62 \% \pm 0,3$ la $0,4 \% \pm 0,3(\mathrm{p}<0,02)$.

Concluzii: Am demonstrat o tendință de modificare a mortalităţii în ultimii şase ani, de asemenea a duratei spitalizării, precum şi o tendință de creştere a utilizării procedurilor laparoscopice, care poate fi principala cauză a acestor schimbări.

Cuvinte cheie: Bina, bază de date, mortalitate, tendințe, secții de chirurgie.

\section{Introducere}

Sistemele computerizate reprezintă o sursă inepuizabilă pentru date statistice şi medicale, care ne ajută să recunoaştem schimbările în tendințe şi să stabilim strategii pentru îngrijiri mai bune, în principal datorită modificării condițiilor practicii chirurgicale în ultima decadă [1]. Progresele tehnologice precum endoscopia şi chirurgia laparoscopică şi alte terapii medicale, sunt asociate cu scăderea numărului de pacienți internați [2].

Pe de altă parte, deşi traumatismele determinate în special de accidentele de circulaţie şi de conflicte, reprezintă o problemă de sănătate tot mai importantă [3], în Spitalul Hasharon acest motiv nu a constituit cauza principală a internărilor şi intervenţiilor chirurgicale.

Scopul acestui studiu a fost de a evalua tendințele în ceea ce privesc internările, demografia, procedurile chirurgicale majore şi rata mortalității, în ultimii cinci ani.

\section{Materiale şi metode}

Spitalul Hasharon, parte a Centrului Medical Rabin din Israel, este un spital secundar comunitar situat în oraşul Petach-Tikva, având 300 paturi. Divizia chirugicală constă din două secții de chirurgie generală, fiecare cu 30 de paturi.

Am colectat şi analizat datele privind rata internărilor în funcție de vârstă, sex, durata internării, rata reinternărilor, distribuția zilnică şi sezonieră a internărilor, procedurile majore chirurgicale şi rata mortaliății. Datele au fost colectate la internare la ambele secții de chirurgie generală, între 2002 şi 2007. Internările pentru alte proceduri precum cele ortopedice, ORL, ginecologice sau oftalmologice au fost excluse din studiuSursa datelor a constituit-o baza de date "Bina” a Serviciilor de Sănătate Clalit, Israel. "Bina” este un sistem integrat nou, care oferă factorilor de decizie de la nivelul secțiilor şi conducerii executive, date agregate din diferite surse, privind activitățile din toate spitalele deservite de Serviciile de Sănătate Clalit.

Comitetul de Etică Helsinki al Centrului Medical Rabin, Petach-Tikva, Israel, a aprobat studiul. Analiza statistică

Scopul primar al studiului a fost să compare date epidemiologice, diagnostice şi proceduri în perioada 2002-2007. Analiza statistică a fost efectuată utilizând programul Microsoft Excel, incluzând testul T cu două brațe presupunând variante egale. Calculul probabilității a folosit indicele de confidență, cu p<0,05 considerat ca semnificativ. Întrucât datele au fost generale pentru toate procedurile şi internările chirugicale, nu au fost necesare corecții epidemiologice. 


\section{Rezultate}

Datele privind timpul, durata internării, vârstă, sex, statusul la control şi mortalitatea, au fost disponibile pentru 26.312 internări între 2002 şi 2007, iar tipul procedurilor şi datele privind caracterul de urgență au fost disponibile pentru 18.663 proceduri chirurgicale între 2002 şi 2007.

Rata anuală a internărilor a fost $4.385 \pm 130$. Nu au existat diferențe semnificative în ceea ce priveşte rata internării în perioada examinată. Majoritatea (52\%) pacienților internați au fost de sex masculin, având vârsta medie de $58,4 \pm 18,1$ ani, cu o proporție de $23,15 \%$ peste 75 ani (Figura 1). Durata medie a internării a fost de 3,2 $\pm 0,2$ zile, având un declin semnificativ de la 3,28 $\pm 0,25$ zile în

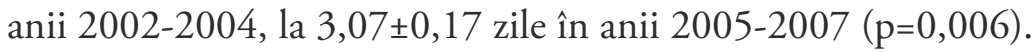

Rata pacienților reinternați într-o săptămână de la externare a fost de $1,4 \% \pm 0,7$ şi respectiv de $2,6 \% \pm 1$ în decurs de o lună de la externare (Tabel I). A existat un declin semnificativ al ratei reinternărilor în decurs de o săptămână, de la 1,68\% $\pm 0,61$ în anii 2002-2003 la 1,13\% $\pm 0,44$ în anii 2006-2007 (p=0,002), iar în rata reinternărilor în decurs de o lună, de la 2,89\% 0 ,89 în anii 20022003, la 2,2\% 0,82 în anii 2006-2007 (p=0,008).

Rata generală a mortalității intraspitaliceşti a fost de $0,5 \%$, cu un declin semnificativ de la $0,62 \% \pm 0,3$ în anii 2002-2003 la 0,4\% 0,3 în anii 2006-2007 ( $\mathrm{p}=0,02)$.

Declinul semnificativ al mortalității intraspitaliceşti se referă la pacienții care au fost supuşi rezecțiilor colice şi rectale, cu un declin constant de la 6,25\% în anii 2002-2004 la 4,5\% în anii 20052007 ( $\mathrm{p}<0,0001)$.

Media anuală a intervențiilor de urgență a fost de 414 (13,4\% din toate intervențiile). O scădere semnificativă a operațiilor în afara urgențelor a fost observată primăvara-vara, cu o medie de $218 \pm 89$ operații pe lună între aprilie-septembrie, comparativ cu $244 \pm 45$ între octombrie-martie $(p=0,005)$. În cazul operațiilor de urgență nu am identificat o distribuție sezonieră.

Distribuția intervențiilor efectuate a fost: 26\% la nivelul anusului, 19\% operații ale apendicelui şi 15\% alte operații ale regiunii abdominale (Figura 2).

Media anuală a operațiilor în afara urgențelor a fost de $2693 \pm 413$. Distribuția operațiilor efectuate în afara urgențelor a fost: 24\% hernioplastii, 13\% operații la nivelul anusului, 10\% la sân, $10 \%$ la piele şi țesuturi moi (lipoame, sinus pilonidal, etc), 10\% operații pe intestinul gros, $9 \%$ colecistectomii şi 9\% operaţii ale vaselor sangvine (Figura 3).

În cei şase ani evaluați în acest studiu, 2,85\% din pacienți au necesitat reintervenții în decurs de 30 de zile. A existat o scădere demnificativă a incidenței intervențiilor recurente, de la 3,5\% în anii 2002-2004 la 2,03\% în anii 2005-2007 (p<0,0001). Dintre intervențiile recurente, 45\% au fost la nivelul abdomenului şi rectului, $18 \%$ la sân, $11 \%$ la nivelul vaselor, $5 \%$ pentru hernie şi $4 \%$ la nivelul veziculei biliare şi tractului biliar.

\section{Operații la nivelul colonului şi rectului}

In cadrul operațiilor efectuate pe intestinul gros, $40 \%$ au fost rezecții ale rectului, $28 \%$ hemicolectomii drepte, $21 \%$ sigmoidectomii, 10\% hemicolectomii stângi şi 1\% rezecții ale colonului transvers.

A existat o creștere constantă a procentului rezecțiilor colice laparoscopice (hemicolectomii drepte şi stângi şi sigmoidectomii), de la 20\% în 2002-2004 la 37\% în 2005-2007 (p<0,0001) (Figura 4).

Vârsta medie a pacienților supuşi rezecției colice sau rectale a fost de 70 ani. Majoritatea pacienților (38\%) au avut 75 de ani sau peste, 31\% între 65 şi 74. Procentul pacienților sub 64 de ani a fost $31 \%$, doar $12 \%$ au fost sub 55 .

Deşi nu au fost modificări ale vârstei medii a pacienților supuşi rezecției colice, procentul pacienților sub 85 de ani a crescut constant de la 5,8\% în 2002 la 8,8\% în $2007\left(r^{2}=0,76\right)$.

Durata internării pacienților cu rezecție colică a fost în medie de 8,2 zile. Pacienții cu rezecție parțială colică deschisă au fost internați pe o periadă mai lungă cu două zile şi jumătate decât pacienții cu rezecție parțială colică laparoscopică (Tabel II). 


\section{Operații la nivelul sânului}

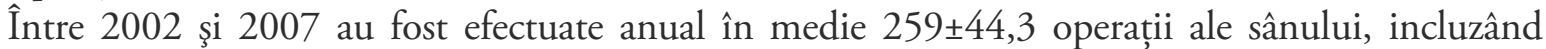
biopsii deschise, lumpectomii şi mastectomii (41,8\%, 47,3\% şi respectiv 10,9\% din operații). Procentul lumpectomiilor din toate operațiile pe sân a crescut de la 32\% în 2002 la 59\% în 2007 ( $\mathrm{r}^{2}=0,93$ pentru tendință). Durata internării după intervenția la nivelul sânului a fost de $1,1 \pm 0,4$ zile pentru biopsiile

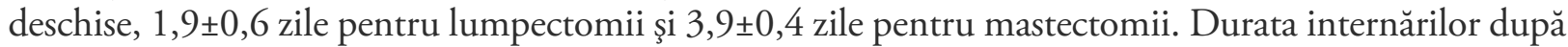
lumpectomii a scăzut de la o medie de 2,51 zile în 2002-2003 la 1,59 zile în 2006-2007 $\left(\mathrm{r}^{2}=0,59\right.$

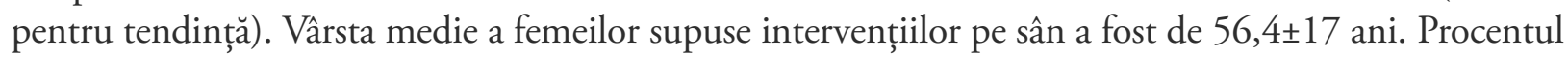
pacientelor tinere (sub 40 de ani) supuse lumpectomiei sau mastectomiei radicale a crescut constant de la 3,83\% în 2002-2003 la 5,38\% în 2006-2007 ( $\mathrm{r}^{2}=0,5$ pentru tendință) (Figura 5).

\section{Colecistectomii}

Între 2002 şi 2007 au fost efectuate în medie 288 24 colecistectomii pe an, din care 6,8\% au fost colecistectomii deschise. A fost constatată o reducere semnificativă a procentajului de colecistectomii deschise vs. laparoscopice, de la 10,5\% în 2002 la 4,9\% în $2007\left(\mathrm{r}^{2}=0,79\right.$ pentru tendință).

Durata internării a fost semnificativ mai lungă pentru colecistectomia deschisă față de cea laparoscopică $(6,6 \pm 0,8$ vs. $2,4 \pm 0,13$ zile, $\mathrm{p}<0,0001)$. Pacienții supuşi colecistectomiei deschise au fost semnificativ mai în vârstă $(34,5 \%$ au avut peste 75 de ani în intervenția deschisă, vs. 13,9\% în laparoscopică, $\mathrm{p}<0,0001)$. Din punct de vedere al sexului a predominat cel masculin $(47,1 \%$ în deschisă vs. 30,1\% în laparoscopică, $\mathrm{p}=0,0001)$.

\section{Hernioplastii}

Au fost efectuate între 2002 şi 2007 un număr mediu anual de $727 \pm 72$ hernioplastii, incluzând: inghinale unilaterale (48\%), inghinale bilaterale (24\%), incizionale (12\%), ombilicale (8\%) şi femurale (1\%) (Figura 6).

Majoritatea pacienților supuşi hernioplastiilor inghinale au fost bărbați (92\%), iar majoritatea hernioplastiilor femurale şi incizionale au fost efectuate la femei (68\% şi respectiv $61 \%)$. Nu a fost identificată o diferență semnificativă între sexe în cazul hernioplastiilor ombilicale (54\% au fost de sex masculin).

Vârsta medie a pacienților cărora li s-a efectuat hernioplastie unilaterală sau bilaterală a fost de $60,3 \pm 18$ şi respectiv $56,3 \pm 15$. Vârsta medie a pacienților supuşi hernioplastiei femurale, ombilicale sau incizionale a fost de $66,7 \pm 18,54,2 \pm 14$ şi respectiv $63 \pm 13,3$.

Dintre hernioplastiile unilaterale, $8,3 \%$ au fost laparoscopice, fără modificări în perioada studiată.

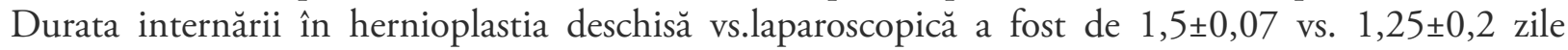
$(\mathrm{p}<0,0001)$.

În cadrul hernioplastiilor bilaterale inghinale, $81 \%$ au fost efectuate laparoscopic, cu o creştere semnificativă a celor laparoscopice de la 71\% în 2002 la 83\% în 2007 (p=0,037). Durata internării pentru hernioplastia inghinală bilaterală deschisă vs. laparoscopică a fost de $1,85 \pm 0,17$ vs. $1 \pm 0,006$ zile $(\mathrm{p}<0,0001)$.

Durata internării pentru hernioplastiile femurale, ombilicale şi incizionale a fost de $2,5 \pm 0,3$, $1,9 \pm 0,2$ şi respectiv $4,3 \pm 0,1$ zile.

\section{Discuții}

În acest studiu am analizat diferitele tendințele în internările pe secțiile de chirurgie ale unui spital comunitar din Israel, în perioada 2002-2007.

În Canada, durata medie a internarii pacienților în anii 2005-2006, a fost de 5,6 zile. Datele noastre indică o durată mai scurtă, de 3,2 zile. Diferența față de durata internării în studiul canadian poate fi atribuită intervențiilor cardiace, toracice şi internărilor pentru traumatisme, neincluse în studiul nostru. 
Conform datelor noastre, pentru pacienții cu rezecție colică sau rectală, durata medie a internării a fost de 8,2 zile. Vârsta medie a fost de 70 de ani, iar procentul pacienților peste 65 de ani a fost de 69\%. Mortalitatea intraspitalicească a fost de 5,4\%.

Comparativ cu Registrul Național de Externări al Statelor Unite în 2005, durata medie a internărilor pentru chirurgia colonului şi rectului a fost similară (8,3 zile), dar pacienții au fost mai tineri. Mortalitatea intraspitalicească a fost similară cu cea a spitalelor non-NCI din Statele Unite (5,5\%) [4]. Aceeaşi tendință a fost observată la compararea datelor din spitalele din California în anul 2000: pacienții au fost mai tineri (vârsta medie de 64,5 ani), durata internării a fost mai lungă $(10,2$ zile), dar mortalitatea intraspitalicească a fost similară (5\%) [5].

Deloc surprinzător, durata internării după colectomia laparoscopică a fost mai scurtă decât după intervenția deschisă. Oricum, şi alți autori au descris aceeaşi tendință, dar cu o durată a internării mai scurtă (5 zile pentru colectomia laparoscopică vs. 6 zile pentru deschisă) [6].

Incidența cancerului de sân a crescut în populația tânără pentru toate rasele, începând cu anii 1980 [7-10]. Rata crescută implică în principal tumorile mici şi localizate, deşi a fost observată de asemenea şi o mică creştere a stadiilor regionale şi a tumorilor mari. Impactul acestei tendințe se reflectă în tipul de intervenție: au fost efectuate mai multe biopsii locale şi lumpectomii decât mastectomii, iar durata internării a fost mai scurtă. Totuşi, în acest studiu, procentul pacientelor tinere (<40 ani) supuse lumpectomiei sau mastectomiei creşte constant de la 3,5\% în 2002 la 6,3\% în 2006. Această tendință a fost de asemena observată în studii epidemiologice recente efectuate în Franța şi Elveția [11,12]. Aceste studii au arătat că screeningul precoce şi depistarea singure nu pot explica creşterea incidenței cancerului mamar în rândul pacientelor tinere, deoarece screeningul şi ameliorarea tehnicilor diagnostice ar trebui să determine modificarea distribuției stadializării în cazul stadiilor precoce, pe când în populația studiată acest lucru nu a avut modificări semnificative.

Introducerea colecistectomiei laparoscopice în ultimii 20 de ani a fost asociată cu o scădere a ratei colecistectomiilor deschise şi o scurtare a duratei internării [13-15]. Aceeaşi tendinţă a fost observată şi în acest studiu, iar această tendință nu s-a modificat în ultimii cinci ani. Am observat că pacienții care au fost supuşi colecistectomiei deschise au fost în special bărbaţi şi mai în vârstă, aceasta fiind în concordanță cu date publicate şi de alți autori $[13,14]$.

Majoritatea hernioplastiilor inghinale unilaterale efectuate în centul nostru medical sunt deschise, iar majoritatea hernioplastiilor inghinale bilaterale sunt efectuate laparoscopic. Datele noastre coincid cu cele descrise de McCormack et al., privind costul-eficiență al hernioplastiilor inghinale, incluzând costul hotelier, costurile îngrijirilor post chirurgicale în afara spitalului şi calitatea vieții [16]. Am determinat că pentru herniile inghinale unilaterale, hernioplastia deschisă costă mai puțin decât cea laparoscopică. Pentru herniile inghinale bilaterale, hernioplastia laparoscopică are o eficiență a costului mai bună decît cea deschisă. Atitudinea noastră este de a alege tehnica cea mai potrivită pentru fiecare pacient cu hernie inghinală, astfel herniile unilaterale sunt operate deschis, iar cele bilaterale sunt rezolvate laparoscopic, dacă situația medicală o permite.

În concluzie, în aprecierea tendințelor în ceea ce privesc internările, am evaluat distribuția procedurilor chirurgicale, cu o atenție specială asupra operațiilor de urgență şi a rezecțiilor parțiale de intestin gros şi rect. Am observat o scădere a duratei medii a internării şi o scădere a mortalităţii, fără a avea modificări în numărul internărilor sau a volumului de proceduri şi a distribuției acestora. De asemenea, am observat că durata internării şi mortalitatea sunt compatibile cu datele publicate anterior în literatură. Aceste informații pot fi importante pentru viitoarele proiecte necesare spitalului nostru. 


\section{References (Referințe)}

1. Trends in Acute Inpatient Hospitalizations and Day Surgery Visits in Canada, 1995-1996 to 2005-2006. Analysis in Brief, Canadian Institute for Health Information. Jan 102007

2. Stein, G. Y, Zeidman, A. Trends in admissions to internal medicine wards in a community hospital in Israel. Eur J Intern Med. 2006;17(4):281-5.

3. DeFrances, CJ, Hall, MJ. 2005 National Hospital Discharge Survey. Adv Data. 2007 ; (385):1-19.

4. Birkmeyer, NJ, Goodney, PP, Stukel, TA, Hillner, BE, Birkmeyer, JD. Do cancer centers designated by the National Cancer Institute have better surgical outcomes? Cancer. 2005;103(3):435-41

5. Liu, JH, Etzioni, DA, O’Connell, JB, Maggard, MA, Hiyama, DT, Ko, CY. Inpatient surgery in California: 1990-2000. Arch Surg. 2003;138(10):1106-11.

6. Clinical Outcomes of Surgical Therapy Study Group. A comparison of laparoscopically assisted and open colectomy for colon cancer. N Engl J Med. 2004;350(20):2050-9

7. Ghafoor, A, Jemal, A, Ward, E, Cokkinides, V, Smith, R, Thun, M. Trends in breast cancer by race and ethnicity. CA Cancer J Clin. 2003;53(6):342-55. Erratum in: CA Cancer J Clin. 2004;54(3):181

8. Jemal, A, Siegel, R, Ward, E, Murray, T, Xu, J, Smigal, C, Thun, MJ. Cancer statistics, 2006. CA Cancer J Clin. 2006;56(2):106-30.

9. Li, CI, Anderson, BO, Daling, JR, Moe, RE. Trends in incidence rates of invasive lobular and ductal breast carcinoma. JAMA. 2003;289(11):1421-4.

10. King, SE, Schottenfeld, D. The "epidemic" of breast cancer in the U.S.--determining the factors. Oncology (Williston Park). 1996;10(4):453-62.

11. Bouchardy, C, Fioretta, G, Verkooijen, HM, Vlastos, G, Schaefer, P, Delaloye, JF, Neyroud-Caspar, I, Balmer, Majno, S, Wespi, Y, Forni, M, Chappuis, P, Sappino, AP, Rapiti, E. Recent increase of breast cancer incidence among women under the age of forty. Br J Cancer. 2007;96(11):1743-6

12. Colonna, M, Delafosse, P, Uhry, Z, Poncet, F, Arveux, P, Molinie, F, Cherie-Challine, L, Grosclaude, P; FRANCIM Network. Is breast cancer incidence increasing among young women? An analysis of the trend in France for the period 1983-2002. Breast. 2008;17(3):289-92.

13. Steiner, CA, Bass, EB, Talamini, MA, Pitt, HA, Steinberg, EP. Surgical rates and operative mortality for open and laparoscopic cholecystectomy in Maryland. N Engl J Med. 1994;330(6):403-8

14. Zacks, SL, Sandler, RS, Rutledge, R, Brown, RS Jr. A population-based cohort study comparing laparoscopic cholecystectomy and open cholecystectomy. Am J Gastroenterol. 2002;97(2):334-40.

15. Hendolin, HI, Pääkönen, ME, Alhava, EM, Tarvainen, R, Kemppinen, T, Lahtinen, P. Laparoscopic or open cholecystectomy: a prospective randomised trial to compare postoperative pain, pulmonary function, and stress response. Eur J Surg. 2000;166(5):394-9.

16. McCormack, K, Wake, B, Perez, J, Fraser, C, Cook, J, McIntosh, E, Vale, L, Grant, A. Laparoscopic surgery for inguinal hernia repair: systematic review of effectiveness and economic evaluation. Health Technol Assess. 2005;9(14):1-203.

\section{Tables and Figures (Tabele şi figuri)}

Table (Tabel) I. Admission Statistics (Date statistice privind internările)

\begin{tabular}{lcccccc}
\hline \multicolumn{1}{c}{ Data (date) } & \multicolumn{7}{c}{ Years (ani) } \\
\hline & $\mathbf{2 0 0 2}$ & $\mathbf{2 0 0 3}$ & $\mathbf{2 0 0 4}$ & $\mathbf{2 0 0 5}$ & $\mathbf{2 0 0 6}$ & $\mathbf{2 0 0 7}$ \\
\hline $\begin{array}{l}\text { Hospitalization } \\
\text { (spitalizări) }\end{array}$ & 4,496 & 4,353 & 4,589 & 4,278 & 4,341 & 4,255 \\
$\begin{array}{l}\text { Duration of Stay/days } \\
\text { (durata internării/zile) }\end{array}$ & 3.3 & 3.2 & 3.2 & 3.1 & 3.1 & 3.1
\end{tabular}


Age/years

(vârsta/ani)

Total Number of Operation

(numărul total de operații)

Number of Urgent Operation

(numărul de operații de urgență)

Returning within a Month (\%)

(reintervenția în decurs de o lună, \%)

Deaths (\%)

(decese \%) $\begin{array}{lllll}57.9 & 58.2 & 58.8 & 58.7 & 58.6\end{array}$

58.2

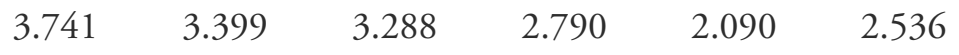

$439 \quad 454 \quad 464 \quad 376 \quad 386 \quad 385$

$\begin{array}{llllll}2.8 & 3.0 & 2.6 & 3.0 & 2.3 & 2.0\end{array}$

$\begin{array}{llllll}0.69 & 0.57 & 0.41 & 0.47 & 0.41 & 0.38\end{array}$

Table (Tabel) II. Duration of stay for partial colon resection (Durata internării pentru rezecția parțială de colon)

\begin{tabular}{lcc}
\hline \multicolumn{1}{c}{$\begin{array}{c}\text { Procedure } \\
\text { (procedura) }\end{array}$} & $\begin{array}{l}\text { Duration of Stay/days } \\
\text { (durata internării/zile) }\end{array}$ & p \\
\hline $\begin{array}{l}\text { Right Hemicolectomy } \\
\text { (hemicolectomie dreaptă) }\end{array}$ & 9.4 & 0.002 \\
$\begin{array}{l}\text { Laparoscopic Right Hemicolectomy } \\
\text { (hemicolectomie dreaptă laparoscopică) }\end{array}$ & 6.8 & 0.03 \\
$\begin{array}{l}\text { Left Hemicolectomy } \\
\text { (hemicolectomie stângă) }\end{array}$ & 9.1 & \\
$\begin{array}{l}\text { Laparoscopic Left Hemicolectomy } \\
\text { (hemicolectomie stângă laparoscopică) }\end{array}$ & 6.5 & $<0 / 0001$ \\
$\begin{array}{l}\text { Sigmoidectomy } \\
\text { (sigmoidectomie) }\end{array}$ & 8.7 & \\
$\begin{array}{l}\text { Laparoscopic Sigmoidectomy } \\
\text { (sigmoidectomie laparoscopică) }\end{array}$ & 5.6 & \\
$\begin{array}{l}\text { Resection of rectum } \\
\text { (amputație de rect) }\end{array}$ & 7.9 & \\
\hline
\end{tabular}

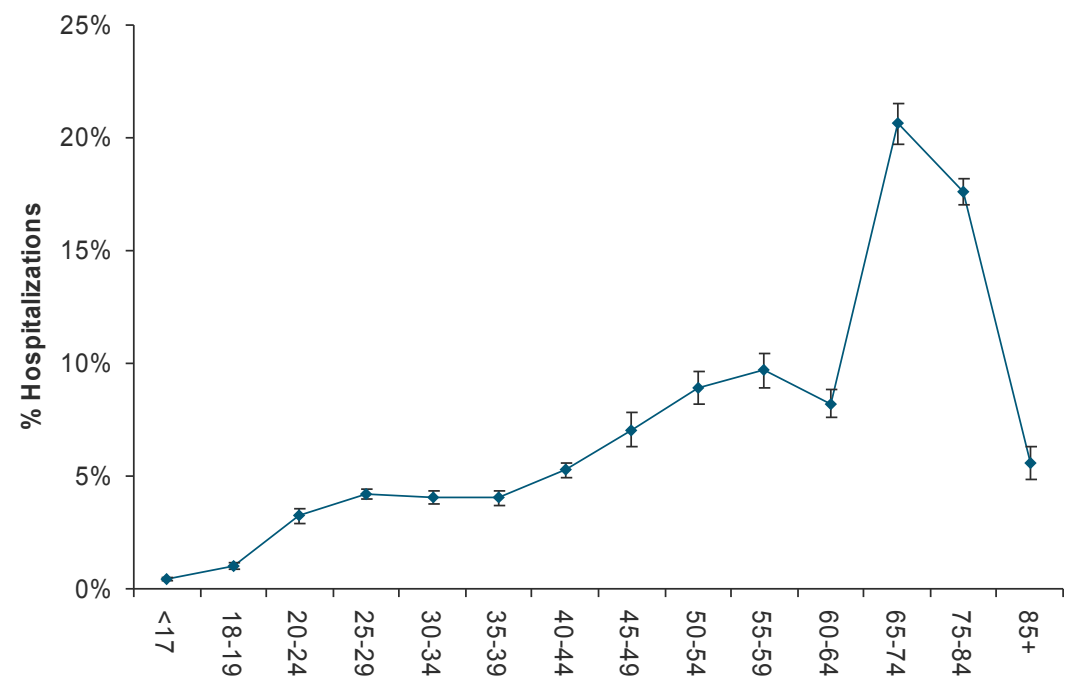

Figure (Figura) 1. Age distribution of hospitalized patients (Distribuția pe grupe de vârstă a pacienților spitalizați) 


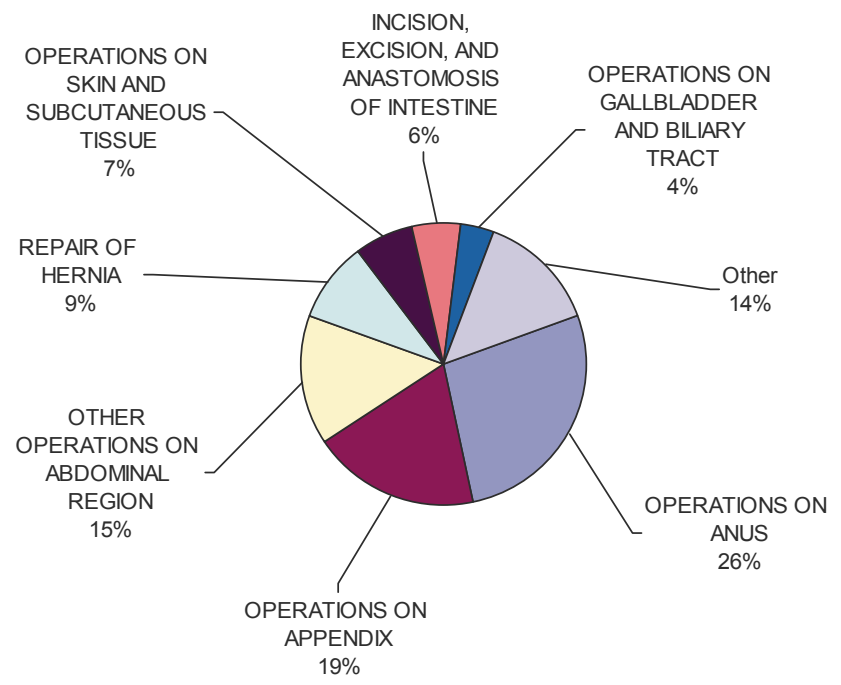

Figure (Figura) 2. Distribution of urgent operations (Distribuția operațiilor de urgență)

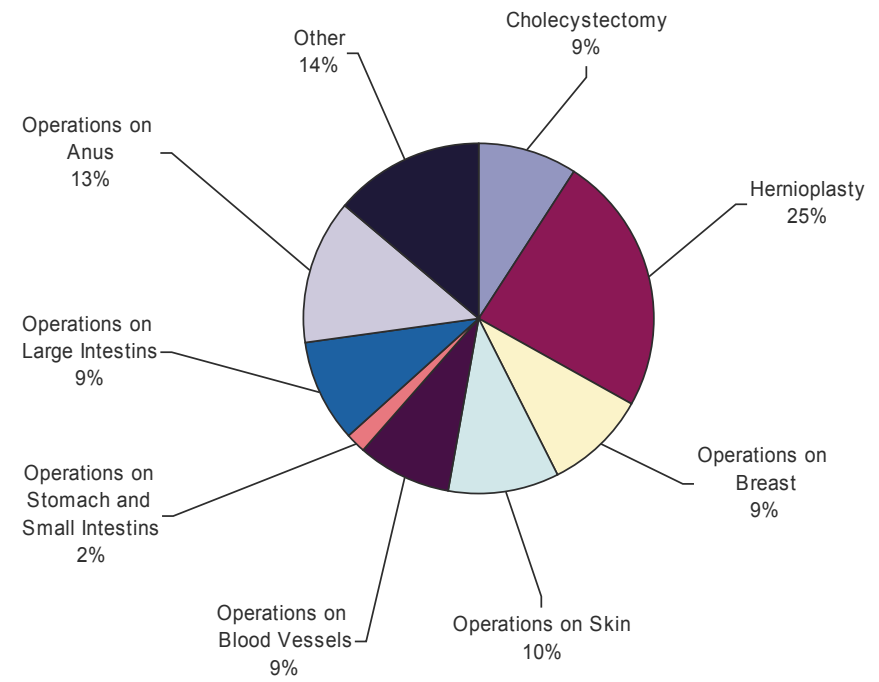

Figura (Figura) 3. Distribution of elective operations

(Distribuția operațiilor în afara urgenței)

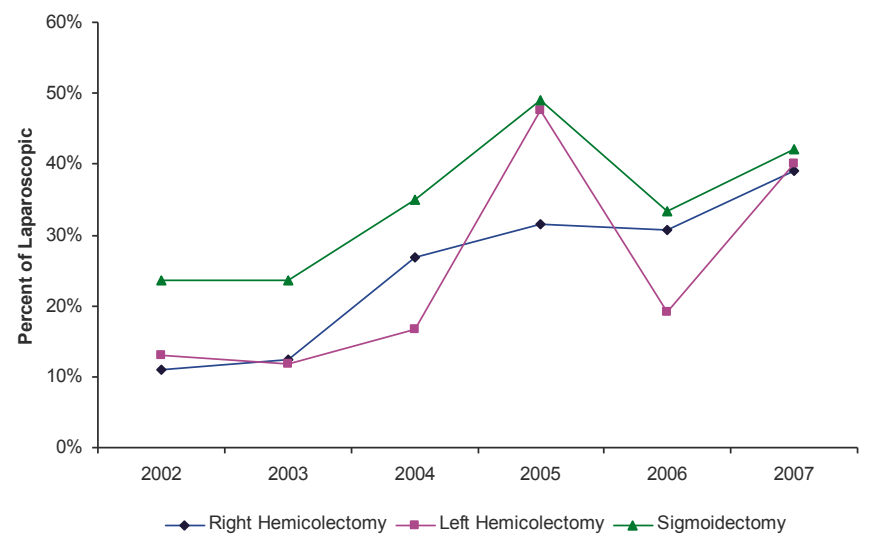

Figure (Figura) 4. Yearly trend of laparoscopic procedures

(Tendința anuală a procedurilor laparoscopice) 


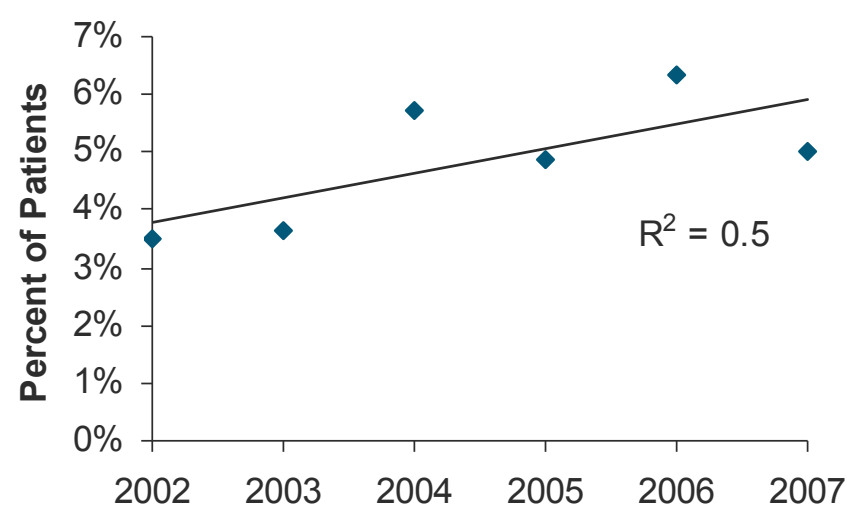

Figure (Figura) 5. Percentage of young patients undergoing lumpectomies or mastectomies (Procentul pacientelor tinere supuse lumpectomiei sau mastectomiei)

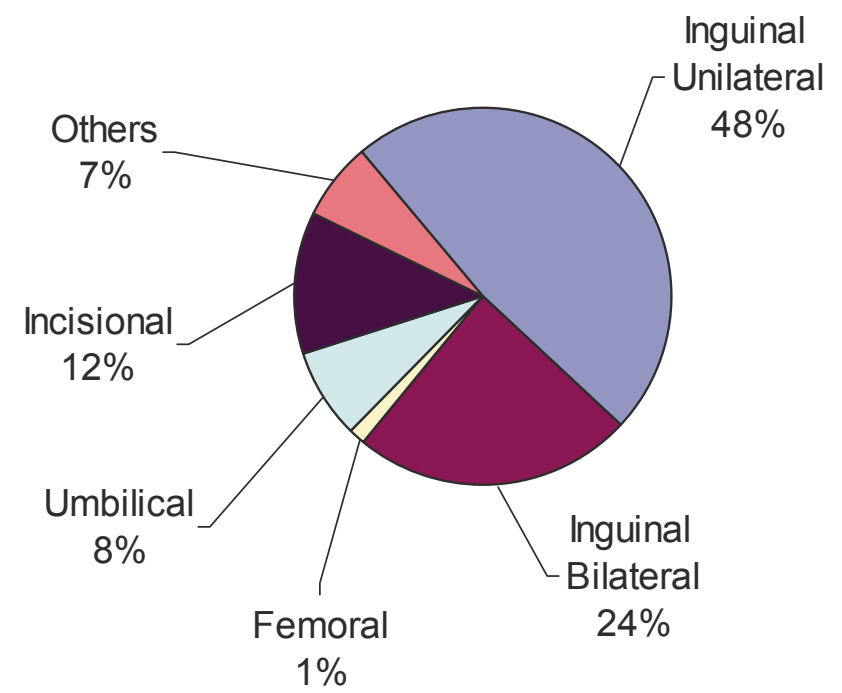

Figure (Figura) 6. Distribution of hernioplasties according to type (Distribuția hernioplastiilor în funcție de tipul lor)

\section{Traducere: dr. Bumbuluț Călin}

